$\overline{\text { 原 著 }}$

\title{
海水の BOD 測定に使用する好気性菌の活性度
}

\author{
堺市衛生研究所 \\ 松本 憲一間宮 孝子 大橋 人士 \\ 西谷 謙二 中島 邦夫 \\ 大阪市立環境科学研究所
}

鶴 保 謙 四 郎

(平成 3 年 7 月 8 日受付)

(平成 3 年 7 月 30 日受理)

Key words: biochemical oxygen demand, seawater, adenosine triphosphate

\begin{abstract}
要 旨
堺市に打ける臨海地域のある種の企業では，海水を機械の冷却水として取り入れている。そして，排 出する際には，大阪府の公害防止条例（昭和49年改正）により Biochemical Oxygen Demand（生物化 学的酸素要求量)規制の適用を受けている。しかし，海水を含む試料の BOD 測定法は，いまだ確立され ていない。

そこで，我々は，その測定法を確立するため，使用する植種水中の好気性菌の活性度の強さと希釈水 の検討を行った.

その結果, 植種水には, 一般細菌数が $10^{3}$ 個 $/ \mathrm{ml}$ 以上, Adenosin triphosphate が $0.50 \mu \mathrm{g} / l$ 以上の值を それぞれ示す活性のある培養海水を，また希釈水には人工海水をそれぞれ使用すれば良いことがわかっ た。
\end{abstract}

\section{I. 緒 言}

海水を含む試料の BOD (Biochemical Oxygen

Demand: 生物化学的酸素要求量 以下 BOD 略す）測定法は，多くの問題点があるにもかかわ らずその研究例は少なく，また文献も若干見られ るだけである。さらに工場排水試験方法 (JISK0102-1986 ${ }^{1)}$; 以下 JIS 法と略す) として は，まだ確立された測定方法が見つかっていない のが現状である。しかし，当所では，このような 試料の BOD 測定の検査依頼がときにみられるた め, より正確な BOD 測定方法を確立する必要が ある。

海水を含む試料の BOD 測定においては，まず

別刷請求先：（干590）堺市甲斐町東 3 丁目 2 番 8 号 堺市衛生研究所

中島 邦夫
適切な条件の植種水，希釈水を使用しなければな らない.

今回， 1 年間を通じて安定した BOD 值を得る ために, 検討を加え使用する植種水中の好気性菌 及びその活性度の強さを調査し，また，希釈水と して人工海水（アクアマリン）を常時使用するこ とを試みた。

その結果, 海水を含む試料の BOD 測定に良好 な結果を得たので報告する。

\section{II. 材料と方法}

1. 実験材料

$\mathrm{BOD}$ 標準物質 ${ }^{1)}$ : 和光純薬 (株) 製のブドウ糖 (無水) 及び L-グルタミン酸の各 $150 \mathrm{mg} / l$ に調整 した混合溶液を使用した。 JIS 法で測定したこの 溶液の BOD 值は, $220 \pm 10 \mathrm{mg} / l$ を示した。 
植種水：天然海水及び河川水を使用した。河川 水としては，大和川の河川水を用いた。 天然海水 としては, 堺市の石津漁港（塩素イオン濃度が $17,000 \mathrm{mg} / l$ 以上）の海水を用いた。

生海水：天然海水を JIS No. 1万紙でろ過した ものを使用した。

人工海水：和光純薬（株）製のアクアマリンを 使用した。

培養海水：和光純薬 (株) 製のブドウ糖 (無水), 和光純薬 (株) 製のポリペプトン各 $0.27 \mathrm{~g}$ を生海水 $3 l$ に溶解し，さらにJIS No. 1万紙でろ過した河 川水 $300 \mathrm{ml}$ を加光, その後 $20^{\circ} \mathrm{C}$ 恒温槽内に执いて, エアーポンプで酸素が飽和状態になるようにばっ 気を行い放置したものを用いた。

トリス緩衝液：和光純薬(株)製のトリスヒド口 キシメチルアミノメタンの特級 $2.95 \mathrm{~g}$ を蒸留水に 溶解し, 塩酸で $\mathrm{pH}$ 值を 7.74 に調整して $1 l$ とした。

Firefly Lantern Extract 溶液：シグマ社製の FLE-50をトリス緩衝液 $10 \mathrm{ml}$ に溶解し，3 時間放 置後上澄み液を使用した。

Adenosine Triphosphate (アデノシンー3ーリン 酸，以下 ATP と略す）標準液：和光純薬（株）製 のアデノシン-3-リン酸 2 ナトリウム, 2 水和物, 生化学用 $1.0 \mathrm{~g}$ を使用時トリス緩衝液で溶解した。

\section{2. 実験方法}

BOD 測定法：JIS 法に準じて行った.

一般細菌数の測定 : 上水試験法 ${ }^{2}$ に従って行っ た。培地は，標準寒天培地を蒸留水及び生海水で それぞれ溶解したものを用いた。

ATP の測定 ${ }^{3)}$ : 培養海水を適量取り，ミリポア フィルター $(0.45 \mu \mathrm{m})$ によってゆっくりろ過し, 吸引儿過ぎないように注意する。その後, 少量の 蒸留水で洗浄する。次に沸騰したトリス緩衝液 10 $\mathrm{ml}$ の中へ，ミリポアフィルターを 5 分間浸漬し ATP を抽出する．直ちに氷水で冷却後 $10 \mathrm{ml}$ 用ス ピッッグラスに移し入れ，トリス緩衝液を加え正 確に $10 \mathrm{ml}$ とした後, 遠心分離 (3,000回転，5 分間) を行った。 その後, 上澄み液を別の小試験管に移 し，測定時玉で冷凍庫 $\left(-20^{\circ} \mathrm{C}\right)$ 中に保存した。

測定に際しては，硬質ガラス製の測定容器に Firefly Lantern Extract 溶液 $1 \mathrm{ml}$ を入れ，次に冷
凍庫から取り出し解凍したものを $1 \mathrm{ml}$ すばやく投 入し，作成した暗箱に入れフタをする。ストップ ウォッチを用い 10 秒後フォトカウンター（浜松ホ トニクス社製の C-1230）のスイッチを押しカウン トを開始する。

生物発光の測定は, フォトカウンターを使用し て10秒間の計数值の平均を 1 秒間当たりのカウン 卜数で表示する.ATP 標準液についても同様に 操作し，両対数用紙に検量線を作成し，試料濃度 を求めた。

\section{3. 実験期間}

BOD 測定及び一般細菌数の測定は, 昭和 62 年か ら平成 2 年の 4 年間のらち特に夏期と冬期に分け て実施した。

次に, ATP 測定は平成元年から元成 2 年の 2 年間に夏期と冬期に分けて実施した。

\section{III. 成 績}

海水を含む試料の BOD 測定は，適切な条件の 植種水，希釈水を使用しなければならない。その ため，以下の方法で検討を行った。

1. 天然海水を植種水とし, 人工海水を希釈水と した場合の BOD 測定

堺市内の石津漁港の天然海水を植種水とし，人 工海水を希釈水として，1 年間のうち夏期と冬期 に分けて BOD 測定を行った。 また, 天然海水の一 般細菌数の検査も行い，その結果を Table 1 に示 した。

夏期 ( 8 月， 9 月)では，天然海水の BOD 值が

Table 1 Biochemical Oxygen Demand value and the general bacteria count of natural Seawater and Biochemical Oxygen Demand value of the standard substance in the summer and winter season

\begin{tabular}{|c|c|c|c|c|c|}
\hline & & \multicolumn{2}{|c|}{$\mathrm{BOD}$} & \multirow{2}{*}{$\begin{array}{c}\text { BOD } \\
\text { of } \\
\text { standard } \\
\text { substance } \\
(\mathrm{mg} / \mathrm{l})\end{array}$} & \multirow{2}{*}{$\begin{array}{c}\text { General } \\
\text { bacteria } \\
\text { count } \\
\text { (cells } / \mathrm{ml})\end{array}$} \\
\hline & & $(\mathrm{mg} / \mathrm{l})$ & $\begin{array}{l}\text { Volume } \\
\text { of } \\
\text { sample } \\
\text { (ml) }\end{array}$ & & \\
\hline \multirow{2}{*}{ Summer } & Aug. & 4.1 & 250 & 229 & $1.9 \times 10^{5}$ \\
\hline & Sept. & 2.1 & 250 & 216 & $2.3 \times 10^{5}$ \\
\hline \multirow{2}{*}{ Winter } & Feb. & 0.9 & 250 & 243 & $1.0 \times 10^{1}$ \\
\hline & Mar. & 0.8 & 250 & 237 & $1.0 \times 10^{3}$ \\
\hline
\end{tabular}


$4.1 \mathrm{mg} / l, 2.1 \mathrm{mg} / l$ となり，一般細菌数がそれぞ れ $1.9 \times 10^{5}$ 個 $/ \mathrm{ml}, 2.3 \times 10^{5}$ 個 $/ \mathrm{ml}$ であった。 また， そのときの標準物質の BOD値がそれぞれ229 $\mathrm{mg} / l, 216 \mathrm{mg} / l$ となり, JIS 法の規定する BOD 值 $220 \pm 10 \mathrm{mg} / l$ の範囲内であった。

冬期 ( 2 月, 3 月) では, 天然海水の BOD 值が $0.9 \mathrm{mg} / l, 0.8 \mathrm{mg} / l$ となり,一般細菌数がそれぞ れ $1.0 \times 10^{1}$ 個 $/ \mathrm{ml}, 1.5 \times 10^{3}$ 個 $/ \mathrm{ml}$ であった。その ときの標準物質の BOD 值がそれぞれ $243 \mathrm{mg} / l$, $237 \mathrm{mg} / l$ となり, JIS 法の規定する BOD 值 $220 \pm$ $10 \mathrm{mg} / l$ の範囲内には入らなかった.

そこで，冬期でも植種水として使用可能にする ため, 天然海水中の細菌を培養することを試みた。

天然海水を JIS No. 1ろ紙でろ過したもの $3 l$ に，栄養源としてブドウ糖，ポリペプトンをそれ ぞれ検討した結果，至適濃度として $0.27 \mathrm{~g}$ 加光溶 解し，さらに JIS No. 1万紙でろ過した河川水 300 $\mathrm{ml}$ を加えた後, 温度 $\left(20^{\circ} \mathrm{C}\right), \mathrm{pH}$ 值 $(7.2)$, エアー ポンプで充分ばっ気を行い, 酸素飽和の状態にし て連続培養を行った。このようにして植種水とし ての培養海水が得られた。

2. 培養海水を植種水とし, 人工海水を希釈水と した場合の BOD 測定

植種水中の好気性微生物のうち特に細菌の影響 を知るため, 培養海水中の一般細菌数の経日変化 を調査し Fig. 1 に示した。

培養 1 日目に括いて一般細菌数が最も多く，そ の後少しずつ減少する傾向があった．Fig. 1 よ り，細菌の活性があるのは，一般細菌数が多い状 態つまり培養 1 日目以降ではないかと推測した。

次に，夏期，冬期に拈ける培養中の培養海水を 植種水として BOD 測定を行った結果，Table 2
Fig. 1 A change with the passage of day of the general bacteria count in the incubation Seawater.

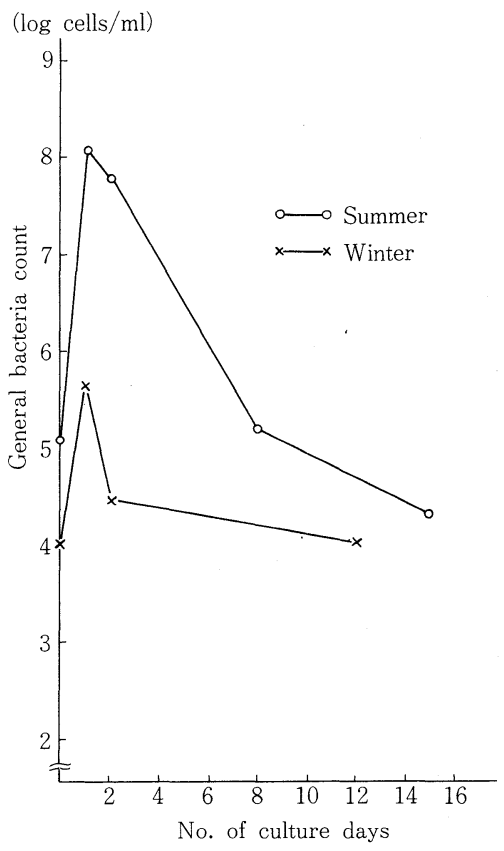

に示す成績となった. 即ち, 標準物質の BOD 值は 培養 1 日目以後のものが殆ど $220 \pm 10 \mathrm{mg} / l$ の範 囲内に入った。

植種水としては培養 1 日目以後の培養海水, 希 釈水としては人工海水をそれぞれ用いることによ り, JIS 法に規定されている標準物質の BOD 值 が $220 \pm 10 \mathrm{mg} / l$ の範囲内に入ることが確認でき た。

冬期では，培養期間の長い培養海水を植種水と したときには，標準物質の BOD 值が $220 \pm 10 \mathrm{mg} /$ $l$ の範囲内に入らなかった。 その原因は, 細菌の活

Table 2 The relation between (Biochemical Oxygen Demand) 5 value of the standard substance and the number of culture days of the incubation Seawater as the culture solution

\begin{tabular}{cccccccc}
\hline & \multicolumn{7}{c}{ No. of culture days } \\
\hline \multirow{3}{*}{ Summer } & & Original & 1 & 2 & 5 & 8 & 15 \\
\cline { 2 - 8 } & $\mathrm{BOD}_{5}(\mathrm{mg} / l)$ & 188 & 210 & 217 & 223 & 212 & 211 \\
\hline \multirow{2}{*}{ Winter } & & Original & 1 & 2 & 5 & 12 & 16 \\
\cline { 2 - 8 } & $\mathrm{BOD}_{5}(\mathrm{mg} / l)$ & 200 & 227 & 229 & 214 & 211 & 262 \\
\hline
\end{tabular}


Fig. 2 The relation between the number of culture day and ATP of incubation Seawater and (Biochemical Oxygen Demand) 5 value of the standard substance.

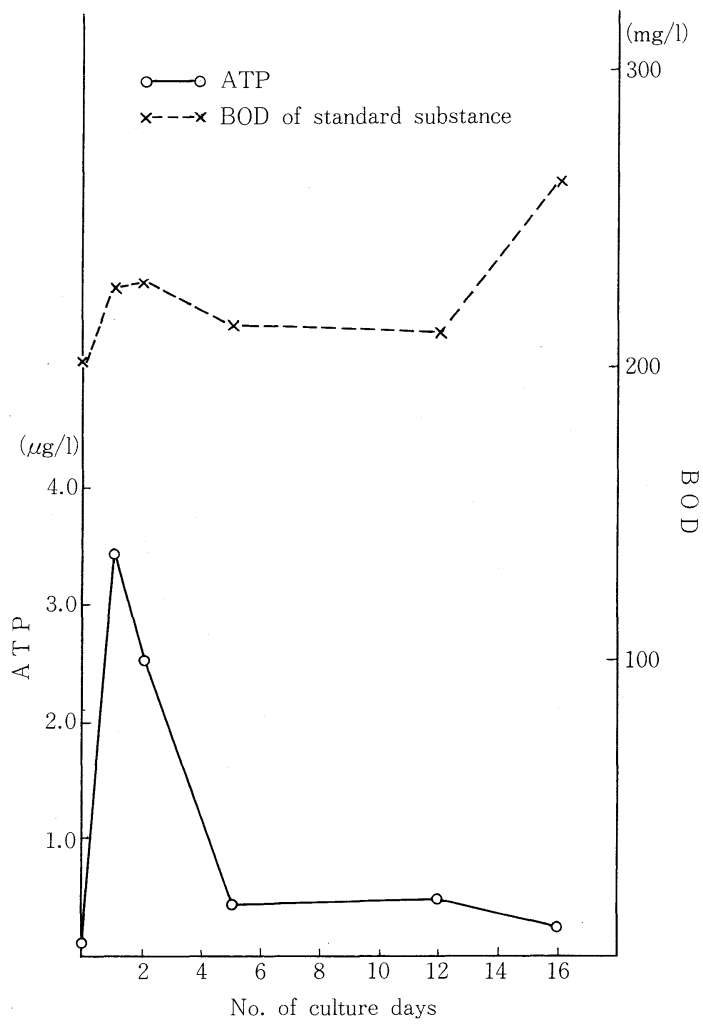

性によるものと考えられるため細菌の活性につい て調査した。

3. 細菌の活性について

培養海水中の細菌の活性について調査するた め，特に冬期に扣いて検討を試みた。

そのため，生細胞中にのみ存在する化学物質で あり, 細胞が死滅すると迅速に分解する ATP 量 を測定すれば良いと考えた。

培養海水中の ATP 量の経日変化を測定し，ま たそのときの標準物質の $\mathrm{BOD}_{5}$ ( 5 日間の BOD 値)を測定したので，その結果をFig. 2 に示した。 Fig. 2 に招いて, 培養海水中の ATP 量は, 培養 1 日目が最も多く,その後減少する傾向がみられた。

\section{IV. 考察}

BOD 測定は，通常，植種水に河川水，希釈水に 蒸留水とイオン交換水の混合したものに栄養源及
び $\mathrm{pH}$ 緩衝液を加えたものを使用して行ってい る。しかし, 海水を含む試料の BOD 測定は, 適切 な条件の植種水，希釈水が必要となる。

竹本 (4) $^{4}$, 植種水, 希釈水に検討を加兄, 良好 な BOD 結果を得たことを報告している。しかし， 現実にはその成果の可否について確認する必要が あろら。このことに関し， 1 年間のうち夏期，冬 期に括いて植種水として使用できるためには，植 種水中の好気性微生物のうち特に細菌が BOD 測 定に関与5)すると言われている。

我々は，植種水として使用する好気性菌の活性 度の強さ及び希釈水として使用する人工海水につ いての検討を行った。

植種水としては, 天然海水（塩素イオン濃度の 高い堺市の石津漁港の海水）を用い，希釈水とし て塩素イオン濃度を一定にするため，人工海水を 用い 1 年間のうち夏期，冬期において BOD 測定 を行った。

植種水として使用する天然海水は，夏期 ( 8 月, 9 月) では，一般細菌数が $10^{5}$ 個 $/ \mathrm{ml}$ 程度とかなり 多く，これを使用しての標準物質の BOD值が JIS 法の規定範囲内であった。

冬期 ( 2 月， 3 月)では, 一般細菌数が $10^{1}$ 個 $10^{3}$ 個 $/ \mathrm{ml}$ 程度と少なく，これを使用しての標準物質 の BOD 値は JIS 法の規定範囲内に入らなかっ た.

その結果，冬期では，天然海水をそのまま植種 水として用いることができないと判断した。

冬期でも植種水として使用可能にするために は, 天然海水中の細菌が BOD 值に大きく関与 ${ }^{5)}$ ていると言われており，その細菌を培養すること を考学た．天然海水に分解されやすくしかも有機 物量の少ない栄養源を加えることにより培養海水 を調整した。

したがって, 植種水としては培養海水を, 希釈 水としては人工海水をそれぞれ使用して BOD 測 定を行った。 その結果, JIS 法に規定されている標 準物質の BOD 值は, $220 \pm 10 \mathrm{mg} / l$ の範囲内に 入った。

通常，植種水として使用している河川水は，一 般細菌数が培養海水よりも少ないときもあるにも 
かかわらず，標準物質の BOD 值が JIS 法に規定 されている $220 \pm 10 \mathrm{mg} / l$ を示した.

このことは，植種水中の細菌の活性に関係する と考えられ, 細菌が活性のある状態のものを植種 水として使用し， BOD 测定を行兄ば良いと考光 た。

したがって, 培養海水中の細菌の活性を調査す るには, 生細胞中にのみ存在する化学物質であり, 細胞が死隇すると迅速に分解する ATP 量を測定 すれば良いと考えた。一細胞あたりの ATP 量は, 種々の微生物についてほぼ一定（約 $0.5 \times 10^{-15} \mathrm{~g}$ $\mathrm{ATP} /$ cell)であり，バクテリアの生物量及び活性 の間接指標として用いられている。

次に, 培養海水中の ATP 量の経日変化と標準 物質の $\mathrm{BOD}_{5}$ 值との関係をみれば，培養 1 日目か ら12日目までは，JIS 法に規定されている標準物 質の $\mathrm{BOD}_{5}$ 值 $220 \pm 10 \mathrm{mg} / l$ の範囲内に入ってい るが，培養初日と培養16日目は， $\mathrm{BOD}_{5}$ 值 $220 \pm 10$ $\mathrm{mg} / l$ の範囲内に入っていなかった。

JIS 法で規定されている標準物質の BOD 值を 示すには, 培養海水を植種水として使用する場合, $\mathrm{ATP}$ 量が $0.50 \mu \mathrm{g} / l$ 以上必要と考兄られた。

今回調查した結果, ATP 量は $0.50 \mu \mathrm{g} / l$ 以上で あり，そのときの一般細菌数は $10^{3}$ 個 $/ \mathrm{ml}$ 以上であ れば, JIS 法に規定されている標準物質の BOD 值 $220 \pm 10 \mathrm{mg} / l$ を示した。
以上のような条件を満たした植種水を用いるこ とにより，より正確な BOD 值を得ることが可能 となった。

今後我が国に打いて，この測定方法により瀬戸 内海等の海水の污濁の指標として, COD (Chemical Oxygen Demand: 化学的酸素要求量) と同様 $\mathrm{BOD}$ も污濁の指標として採用可能であると思わ れる。

本稿を終えるにあたり, ご指導, ご協力を頂いた竹本修 明氏(大阪府立消防学校, 前大阪府公害監視センター), 山 本康次氏, 中野 壬氏 (大阪府立公衆衛生研究所), 愛川幸 平氏, 原 嘉造氏（前, 堺市衛生研究所）をはじめ堺市衛 生研究所の微生物担当の方々に深謝いたします。

本研究は，昭和63年度財団法人「大同生命厚生事業団」 の第15回医学研究助成金の援助を受けた。

\section{文献}

1）工場排水試験方法：JIS-KO102. BOD, p. 47-51, 1986.

2）上水試験方法：日本水道協会. 一般細菌，p. 605 $-606,1985$

3）竹本修明, 田中秀穂, 望月京司, 杉前昭好, 中本 雅雄：各種試料中の ATP 分析について。大阪府 公害監視センター調查研究編, No. 7, p. 110-115, 1984.

4) 竹本修明, 三谷悦朗, 松下千明, 田吹伸朗, 久下 芳生，浅田真吾：海水を含を工場排水の BOD に ついて。公害と対策, 14(9) : 77-85, 1978.

5）萩原耕一：BOD 試験法解説（改訂版）. p. 68, 績 文堂, 1977 .

\section{Activation of Aerobic Bacteria Used as BOD Measurement of Seawater}

\section{Kenichi MATSUMOTO, Takako MAMIYA, Hitoshi ŌHASHI, Kenji NISHITANI \& Kunio NAKAJIMA \\ Sakai City Institute of Public Health \\ Kenshirou TSURUHO \\ Osaka City Institute of Public Health and Environmental Sciences}

Waste of seawater used for cooling water for machines in some kinds of industries in a littoral district in Sakai City, comes under the application of BOD control of the pollution control ordinance in Osaka Prefecture. But unfortunately the BOD measurement method of seawater sample has not been established.

In order to establish the measurement method, we studied the strength of activation of aerobic bacteria in the incubation water used and the dilution water.

From our results it was proved that we can use the incubation seawater consisting of more than $10^{3}$ cells $/ \mathrm{ml}$ general bacteria count and more than $0.50 \mu \mathrm{g} / 1$ ATP (Adenosin triphosphate) as the incubation water and the artificial seawater as the dilution water. 